Acta vet. scand. $1973,14,272-277$.

From the Department of Medicine I and the Department of Obstetrics and Gynaecology, Royal Veterinary College, Stockholm, Sweden.

\title{
STUDIES ON THE TRANSMISSION OF ${ }^{125}$ I IgG AND ${ }^{125}$ I ALBUMJN FROM SERUM TO SEMINAL PLASMA IN BOARS
}

\author{
By
}

Kjell Martinsson, Stig Einarsson and Börje Gustafsson

MARTINSSON, KJELL, STIG EINARSSON and BORJE GUSTAFSSON: Studies on the transmission of ${ }^{125 I}$ IgG and ${ }^{125}$ I albumin from serum to seminal plasma in boars. Acta vet. scand. 1973, 14, $272-277$. - Labelled swine albumin resp. IgG were injected intravenously in two boars. The radioactivity of seminal plasma was determined at frequent intervals. It was observed that minimal amounts of radioactivity of albumin and IgG could be detected in seminal plasma. The importance of a transmission of IgG from serum to seminal plasma is discussed.

seminal plasma; immunoglobulins; swine.

Studies on animal seminal plasma proteins are few in number in comparison with those on human ones. Electrophoretic studies on boar seminal plasma proteins have been performed by Bennet (1965) who could separate four different fractions with agar gel electrophoresis. Two of the fractions situated in the albumin-alpha-region were found in a very low concentration. The other two fractions in the beta-gamma-region had a much greater concentration and the total protein concentration was about 2-3 g \%. Boursnell et al. (1962) have shown the seminal vesicles to be the origin of the two major seminal plasma proteins of the boar. The different protein components in boar seminal plasma have hitherto not been identified with immunoelectrophoresis depending on the difficulties to avoid precipitation during the electrophoretic run. In human seminal 
plasma, albumin and gammaglobulin have been identified (Klopstock et al. 1963), and it was suggested that these proteins derived from blood serum.

Alterations of the normal seminal plasma protein pattern were suggested by Szumowski (1961) to be related to the occurrence of pathological characteristics of spermatozoa in bulls. Therefore it may be important to identify the protein components with sensitive techniques i.e. immunoelectrophoresis and to determine the origin of the protein in seminal plasma.

The purpose of this investigation was to study, if serum albumin and serum IgG are transmitted to the seminal plasma in boars, since fractions with electrophoretic mobilities of serum albumin and gammaglobulin have been identified in boar seminal plasma (Bennet).

\section{MATERIAL AND METHODS}

Two boars of Swedish Yorkshire breed were used in this study. The age and live bodyweight of the boars were 8 and 14 months and 115 and $180 \mathrm{~kg}$, respectively. The sperm morphology was examined (cf. Bane 1961) and judged as normal before the experimental procedure.

\section{Labelled protein}

Immunoelectrophoretic pure porcine albumin and IgG (Nutr. Biochem. Corp.) were labelled with ${ }^{125}$ I according to the method of Mc Farlane (1956) ${ }^{\star}$. The boars were injected with about 100 $\mu \mathrm{Ci}$ of ${ }^{125} \mathrm{I}$ albumin and ${ }^{125} \mathrm{I}$ IgG, respectively.

\section{Radioactivity determination}

Blood was drawn from the ear vein at regular intervals (130 days after injection). Semen was collected at the same time in an artificial vagina. After filtering through gauze the semen was immediately taken to the laboratory, the spermatozoa were separated from the seminal plasma by centrifugation for 15 min. at 5,700 r.p.m., and the supernatant was removed.

Testicles and epididymides were obtained at castration of the boars under i. v. narcosis (Intraval $\circledast$ ) 44 and 46 days after inteins.

* Our thanks are due to dr. Renée Norberg for labelling the pro- 


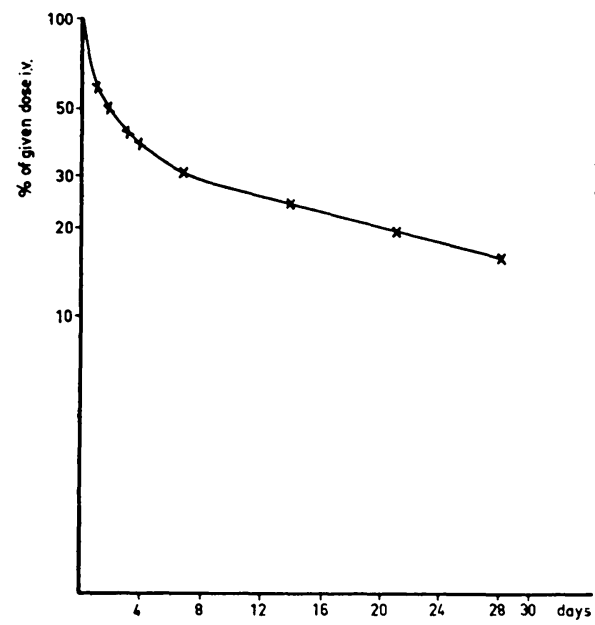

Figure 1 The plasma disappearance curve of labelled IgG given intravenously.

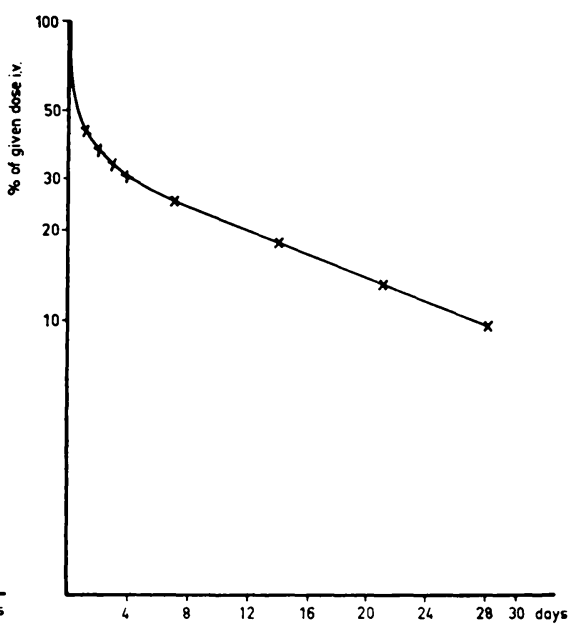

F i g u r e 2. The plasma disappearance curve of labelled albumin given intravenously.

jection. The cauda epididymal content was removed as soon as possible and was centrifugated immediately and samples were taken for radioactivity determinations.

\section{RESULTS}

The blood plasma disappearance curves of the labelled preparations are shown in Figs. 1 and 2. The radioactivity of the seminal plasma expressed as percentage of the corresponding activity in blood plasma was too low to be accurately measured. In all samples this activity was only $0.1-0.3 \%$ of the corresponding values in blood plasma. The same values were found in epididymal plasma from cauda epididymis obtained at castration (44 and 46 days after injection).

The blood plasma volumes of the boars were 44 and $43 \mathrm{ml} / \mathrm{kg}$ bodyweight, respectively. The half-life of the albumin preparation was about 13-14 days judging from the plasma disappearance curve, and the half-life of the IgG preparation was about 22 days.

\section{DISCUSSION}

In the present investigations it was shown that very small amounts of albumin and IgG were transferred to seminal plasma. 
The radioactivity of the seminal plasma was only about $0.1-$ $0.3 \%$ of that in serum.

However, it can not be wholly concluded that this represents the amount of IgG and albumin transferred from serum to the genital system. A transmission followed by a reabsorption to the blood system can not be neglected. Thus Mancini et al. (1965) have shown in rats that IgG and albumin can pass through the germinal epithelium and appear in the tubular lumen. These proteins could not be found in the ductus deferens and it was concluded by Mancini et al. (1965) that a reabsorption exists.

However, of greatest importance are the origin and occurrence of IgG in the seminal plasma with respect to infertility caused by antibodies cytotoxic to homologous spermatozoa which are present at low titer in normal sera of several species ( $E d$ wards 1960, Johnson 1968). The results in the present investigation and those of Johnson \& Setchell (1970) indicate that the entry of appreciable amounts of serum protein into seminal plasma is prevented by a barrier which may also prevent the entry of other proteins such as LH and FSH (Mancini et al. 1967). The presence of this barrier is probably of importance for the immunological reaction in vivo against homologous spermatozoal antigens. Presumably the barrier will also prevent the entry of spermatozoal antigens to the blood system and thus reduce autoimmunization. Also the cytotoxic antibodies present in low titers in serum will not enter the seminal content, and thus lysis of spermatozoa is prevented. Bulls, immunized with testicular homogenate, epididymal homogenate or washed ejaculated spermatozoa, developed circulating antibodies against inoculated components, and in some bulls degenerative lesions in the testes were observed (Losos et al. 1968). However, no antibodies were demonstrated in the seminiferous tubules.

It is possible that the minimal transmission of IgG is of no importance with respect to the immunological reactions with spermatozoa. No reliable immunological methods are available for determination of IgG in seminal plasma since unspecific precipitation often occurs in single radial immunodiffusion tests. Therefore it can not be concluded, whether only serum IgG or locally produced IgG as well are present in seminal plasma. Bennet (1965) have isolated four fractions from boar seminal plasma of which two migrated as beta-gammaglobulins, and these were present in a high concentration. It may indicate that 
also a local production of IgG occurs. In this respect the findings of Boursnell et al. (1962) are of interest, since they have shown that most of the proteins in boar seminal plasma are produced in the seminal vesicles.

Johnson \& Setchell (1970) found that the IgG content in seminiferous tubules in ram was $0.2 \%$ of the serum value, but in seminal plasma the concentration was $2 \%$. This finding may indicate a local production of IgG.

\section{REFERENCES}

Bane, A.: Acrosomal abnormality associated with sterility in boar. Proc. IVth Int. Congr. Animal Reprod. Hague 1961, 4, 810-817.

Bennet, J. P.: Quantitative comparisons of the protein of the seminal plasmas of bull, ram, rabbit, and boar by agar gel electrophoresis. J. Reprod. Fertil. 1965, 9, 217-231.

Boursnell, J. C., P. Johnson \& J. Zamora: An electrophoretic and ultracentrifugal study of boar seminal plasma. Biochim. biophys. Acta (Amst.) 1962, 63, 374-381.

Edwards, $R$. G.: Complementfixing activity of normal rabbit serum with rabbit spermatozoa and seminal plasma. J. Reprod. Fertil. $1960,1,268-282$.

Johnson, M. H.: Characterization of a natural antibody in normal guinea pig serum reacting with homologous spermatozoa. J. Reprod. Fertil. 1968, 16, 403-406.

Johnson, M. H. \& B. P. Setchell: Protein and immunoglobulin content of rete testis fluid of rams. J. Reprod. Fertil. 1970, 17, 403-406.

Klopstock, A., R. Haas \& A. Rimon: Immunoelectrophoretic analysis of seminal plasma. Fertil. and Steril. 1963, 14, 530-534.

Losos, C. J., A. J. Winter \& K. Mc Entee: Induction of testicular degeneration in bulls by isoimmunization. Amer. J. vet. Res. 1968, 29, 2295-2306.

Mancini, R. E., O. Vilar, B. Alvarez \& A. C. Seiguer: Extravascular and intratubular diffusion of labelled serum proteins in the rat testis. J. Histochem. Cytochem. 1965, 13, 376-385.

Mancini, R. E., A. Castro \& A. C. Seiguer: Histologic localization of follicle-stimulating and luteinizing hormones in the rat testis. J. Histochem. Cytochem. 1967, 15, 516-525 .

Mc Farlane, A. S.: Labelling of plasma proteins with radioactive iodine. Biochem. J. 1956, 62, 135-143.

Szumowski, P.: Les protéines du plasma seminal et les troubles de la fertilite des taureaux. (The seminal plasma proteins and problems of fertility in bulls). Proc. IVth Int. Congr. Animal Reprod. Hague 1961, 3, 696-700. 


\section{SAMMANFATTNING}

Studier över transmissionen av jodmärkt IgG och albumin från serum till spermieplasman hos galt.

Radioaktivt albumin resp. IgG från svin tillfördes intravenöst på två galter. Aktiviteten i spermieplasman mättes regelbundet. Det visades att endast mycket låg aktivitet av både albumin och IgG förelåg i spermieplasman. Betydelsen av en transmission av IgG från serum till spermieplasma diskuteras.

(Received March 22, 1972).

Reprints may be requested from: K. Martinsson, Department of Medicine I, Royal Veterinary College, S-104 05 Stockholm 50, Sweden. 